\title{
Pneumomediastinum following a stab wound to the chest
}

\author{
Hosam E Matar, Manojkumar S Nair, Romi Navaratnam \\ Department of General Surgery, North Middlesex University Hospital NHS Trust, London, UK \\ Correspondence to Hosam E Matar, hematar@doctors.org.uk
}

\section{DESCRIPTION}

Pneumomediastinum (PM) relates to air collection around the mediastinal structures. It is classified into spontaneous PM, without any obvious primary source, and secondary PM, with a specific responsible pathologic event, such as trauma, intrathoracic infections or violation of the aerodigestive tract. ${ }^{1}$ The prevalence of PM in major trauma centres ranged from $1 \%$ to $5.2 \%$ of all patients with chest trauma. ${ }^{2}$ PM alone does not predict severe injury, however, it warrants detailed investigation if clinical symptoms are present. ${ }^{2}$

We present a case of a 16-year-old boy who presented to our emergency department with a stab wound to the left chest, at the level of the fourth intercostal space in the midaxillary line. He was haemodynamically stable and saturating $99 \%$ on room air. As shown on chest x-ray (figure 1), a radiolucent outline around the right border of the heart indicated major intrathoracic injuries. ${ }^{3}$ We proceeded with
CT scan of chest that showed bilateral pneumothoraces with PM without significant intrathoracic injuries (figure 2). He underwent conservative treatment as the mediastinum will slowly resorb air into the cavity. Breathing high-flow oxygen will increase the absorption of air.

\section{Competing interests None.}

Patient consent Obtained.

\section{REFERENCES}

1. Rezende-Neto JB, Hoffmann J, Al Mahroos M, et al. Occult pneumomediastinum in blunt chest trauma: clinical significance. Injury 2010;41:40-3.

2. MacLeod JB, Tibbs BM, Freiberger DJ, et al. Pneumomediastinum in the injured patient: inconsequential or predictive? Am Surg 2009;75:375-7.

3. Triaridis S, Konstantinidis I, Noussios G, et al. A diagnostic challenge: investigating suspected tracheobronchial and pharyngoesophageal tears. Are there gold standards? Acta Otorhinolaryngol Belg 2002;56:331-4.

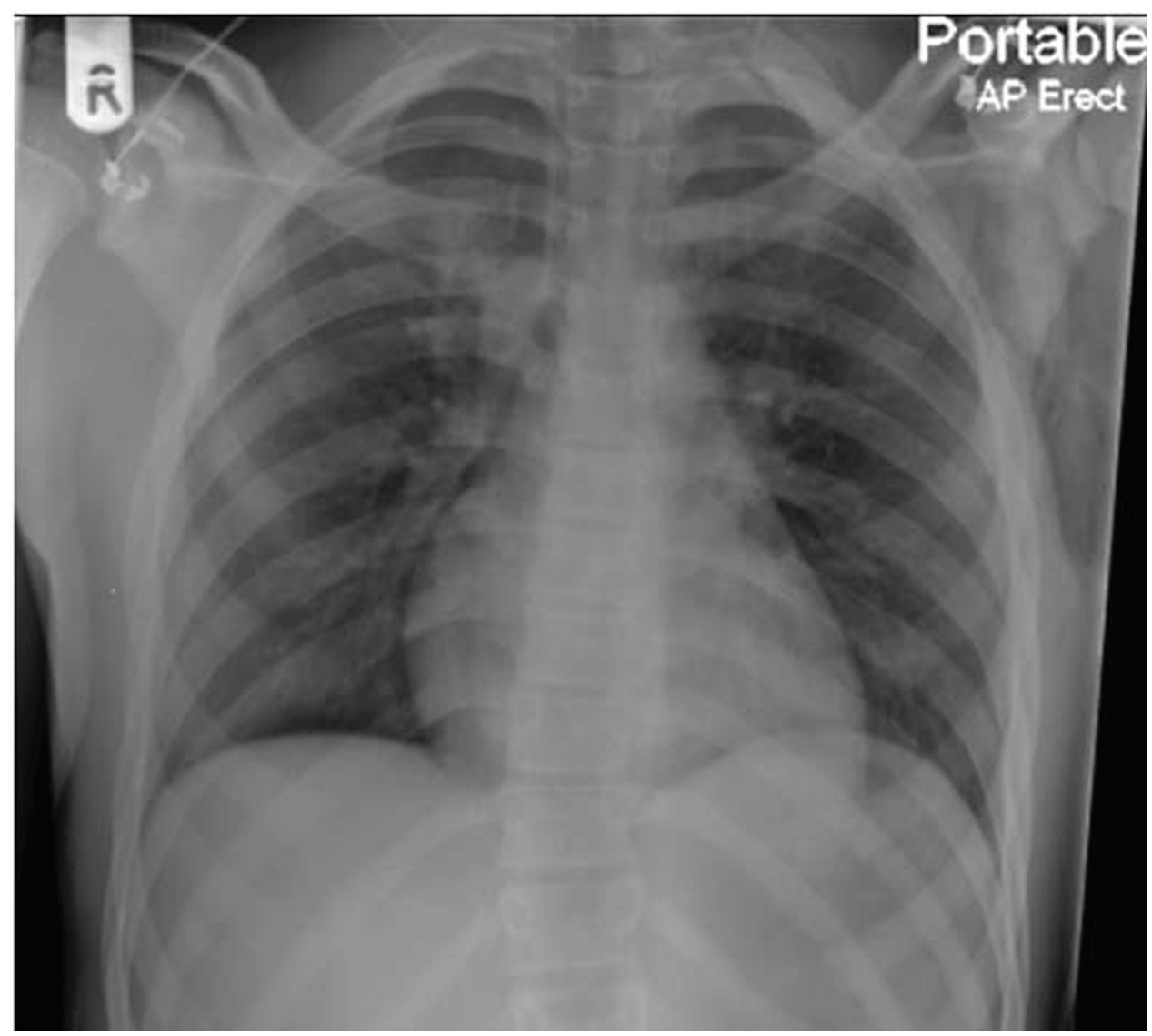

Figure 1 Portable AP chest x-ray with radiolucent outline around the right border of the heart. 


\section{BMJ Case Reports}

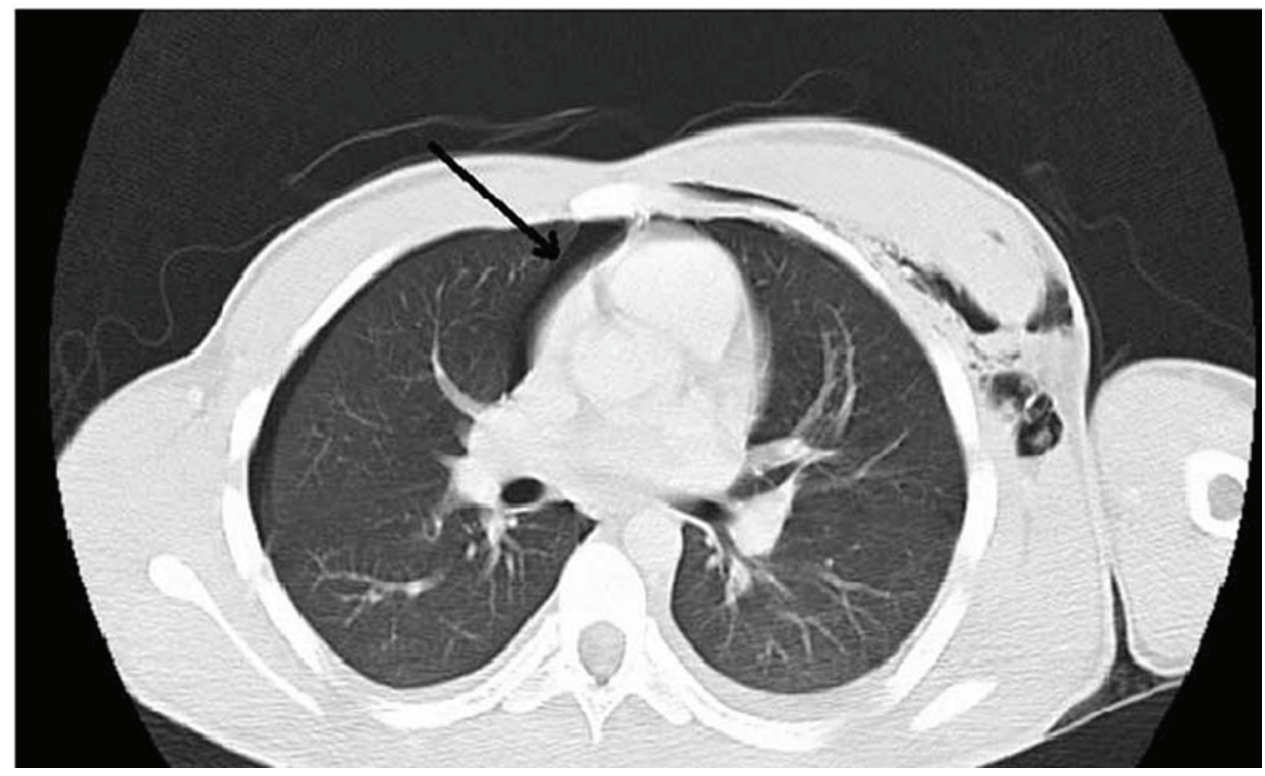

Figure 2 CT scan of the chest with area of pneumomediastinum (arrow).

This pdf has been created automatically from the final edited text and images.

Copyright 2011 BMJ Publishing Group. All rights reserved. For permission to reuse any of this content visit

http://group.bmj.com/group/rights-licensing/permissions.

BMJ Case Report Fellows may re-use this article for personal use and teaching without any further permission.

Please cite this article as follows (you will need to access the article online to obtain the date of publication).

Matar HE, Nair MS, Navaratnam R. Pneumomediastinum following a stab wound to the chest. BMJ Case Reports 2011;10.1136/bcr.11.2010.3495, date of publication

Become a Fellow of BMJ Case Reports today and you can:

- Submit as many cases as you like

Enjoy fast sympathetic peer review and rapid publication of accepted articles

- Access all the published articles

- Re-use any of the published material for personal use and teaching without further permission

For information on Institutional Fellowships contact consortiasales@bmjgroup.com

Visit casereports.bmj.com for more articles like this and to become a Fellow 